\title{
COMPARISON OF GRAVIMETRIC METHOD AND TDR METHOD APPLIED TO MEDIUM ALLUVIAL SOILS OF THE VALLEY OF THE ODER RIVER IN THE REGION OF BRZEG DOLNY IN THE PERIOD OF 2010-2014
}

\author{
Beata Olszewska' ${ }^{1}$ Edyta Nowicka ${ }^{1}$ \\ 1 Institute of Environmental Protection and Development, Wrocław University of Environmental and Life \\ Sciences, pl. Grunwaldzki 24, 50-363 Wrocław, Poland, e-mail: beata.olszewska@up.wroc.pl; edyta.nowicka@ \\ up.wroc.pl
}

Received: 2015.07.14 Accepted: 2015.08.31 Published: 2015.10.01

\begin{abstract}
The paper presents an analysis and comparison of results of measurements of moisture of medium alluvial soils situated in the valley of the Oder river in the region of the barrage at Brzeg Dolny. The study was conducted for two soil profiles, designated as profile " $\mathrm{A}$ " (in the valley adjacent to the barrage) and "B" (below the barrage structure). The measurements were taken at monthly intervals from April till October in the years 2010-2014, with parallel use of the gravimetric method and the TDR method. Correlations of the values of volumetric moisture were determined. The correlation indicates good relationship of the results obtained throughout the whole moisture range.
\end{abstract}

Keywords: valley of the Oder river, soil moisture, methods of soil moisture measurement.

\section{INTRODUCTION}

Moisture content is one of the morphological features of soil profile. Deficient moisture relations in soil are a factor significantly limiting the potential productivity of habitats of plant growth and development. The excess or deficit of water as well as optimum moisture are determined by climatic and hydrological relations, land relief, hydrogeological conditions, soil profile structure, and the level of cultivation technology [Marcilonek 1979]. Soil moisture status depends also on the species and growth phase of plants, groundwater level, and in spring also on the level of soil water resources. Those factors cause that in the territory of Poland a great variation is observed in the moisture status of the surface layer of soil in the vegetation period [Bac et al. 1998]. Hence, the knowledge on the values of volumetric moisture of soil is extremely important. The basic method used for its measurement is the gravimetric method, adopted as a standard [Leciejewski 2009]. Initially, studies of soil moisture were conducted only with the gravimetric method, while at present more and more researchers employ the use of TDR (Time Domain Reflectometry) method in their studies [Biniak-Pieróg 2008, Janik 2005, Oleszczuk et al. 2006, Usowicz and Usowicz 2004]. The application of the TDR technique, due to its low labour and time requirements, is becoming quite common [Malicki 1993, Skierucha, Wilczek 2007]. It should be classified as a modern measurement system, representing current design and development trends and characterised by low power consumption, large capacity in-built memory, and the possibility of control and data transfer to any place in the world via an internet interface. The authors of that technique indicate its non-destructive character as its greatest advantage [Malicki 1993, Skierucha, Wilczek 2007]. The correctness of the application of the TDR method for soil moisture measurements requires verification by means of the classical gravimetric method. Such an analysis, concerning measurements conducted on the medium alluvial soils of the valley of the Oder river, has been presented e.g. in a paper by Łyczko et al. [2000]. Those authors indicate that soil moisture values measured with those two methods are com- 
parable, the differences in the values obtained not exceeding several percentage points. The increasingly popular use of the TDR method induced researchers to undertake studies on the credibility of the method in various specific soil conditions [Kossowski and Usowicz 2000, Oleszczuk et al. 1998]. The aim of a study by Pęczkowski et al. [2007] was to compare the results of moisture measurements conducted with the TDR method and the gravimetric method on soils of mountain regions with a high content of skeleton particles. In all of the analysed cases a high consistency of the results obtained was observed.

\section{MATERIAL AND METHOD}

The construction of the final barrage on the Oder river, at the locality of Brzeg Dolny, caused the division of the valley into two zones with different effects of water levels in the river on the water relations in the adjacent areas. The part of the valley situated above the barrage is additionally supplied with water infiltrating from the reservoir. In this area river Odra assumes an infiltration character. Below the damming structure the situation is different, as lands situated there are under a draining effect of the river [Olszewska 1998, Pływaczyk 1997].

The measurements were taken at monthly intervals from April till October in the years 2010 2014, with parallel use of the gravimetric method and the TDR method. For the purposes of this paper data from moisture measurements of soils sampled by means of a soil drill, in three replications, from the layers of $0-10 \mathrm{~cm}, 20-30 \mathrm{~cm}$, $40-50 \mathrm{~cm}, 65-75 \mathrm{~cm}$ were selected. After drilling to the required depth, measurements were taken with a probe, in two replications, by placing it in the soil layer analysed. The location of the research object is presented in Figure 1.

The measurements of soil moisture were made for two soil profiles. Profile A is located in the area adjacent to the barrage, where the groundwater table is situated at an average level of about 1 $\mathrm{m}$ below the ground level. The profile designated as $B$ is situated in the valley below the barrage at Brzeg Dolny, where the average depth of the groundwater table is about $3.5 \mathrm{~m}$ below ground level. The soil pits are separated from each other by a distance of ca. $5 \mathrm{~km}$, and during the period of the study they were used as arable soils.

Geological studies revealed that the area under analysis is covered with quaternary and tertiary formations. The surface layer of the valley is made up of formations with low permeability and depth of, locally, up to $2.0 \mathrm{~m}$, overlying formations with good permeability and thickness of up to several dozen meters. Such a geological structure creates good conditions for water filtration from the Oder river to the valley and the other way round. Approximately $85 \%$ of the area of the valley is occupied by alluvial soils formed primarily from medium and heavy loams, the remaining $15 \%$ being accounted for by podzolic, brown and organogenic soils [Pływaczyk 1997].

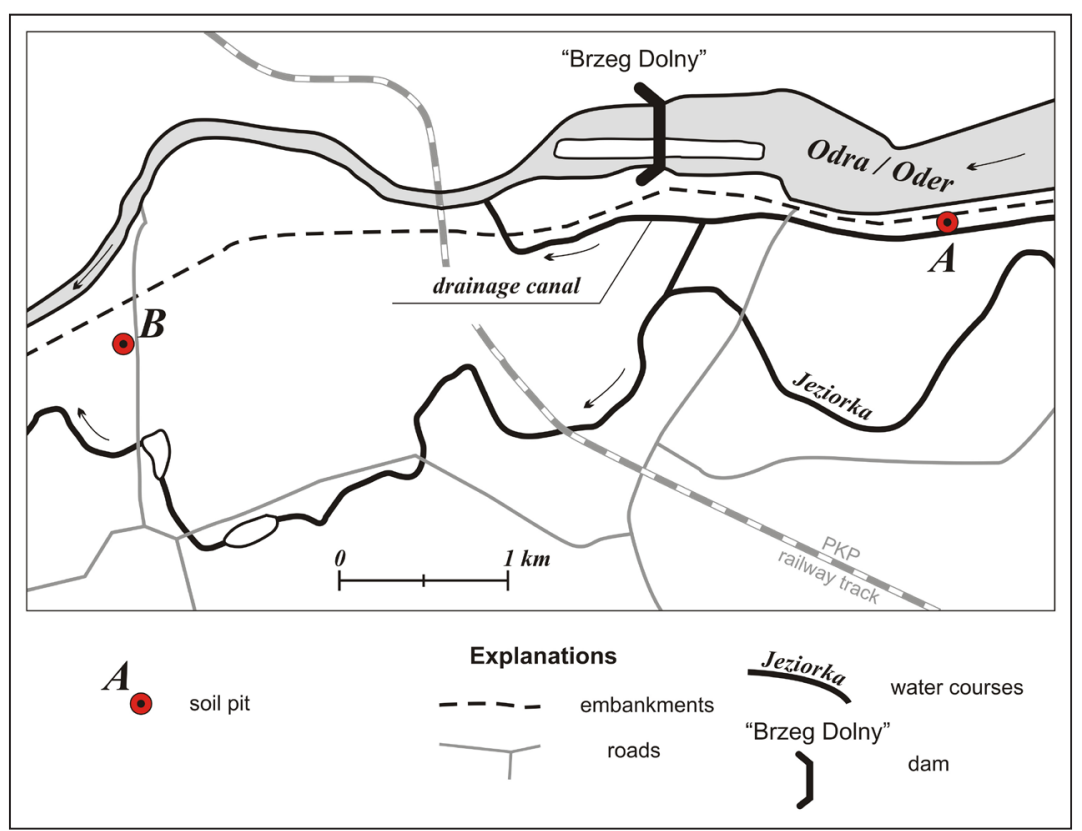

Figure 1. Situation map of the research object 


\section{RESULTS}

Based on the data presented in the paper by Olszewska [1998], a comparison of results of analyses of particle size distribution, physical properties and variation of porosity was performed for the soil profiles under discussion. The results indicate that in both soil pits medium loams lie to the depth of $50 \mathrm{~cm}$, with light loams beneath them to the depth of $75 \mathrm{~cm}$. The bulk density of the soils analysed varies from 1.43 to

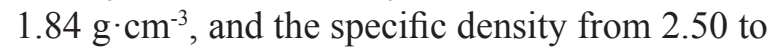

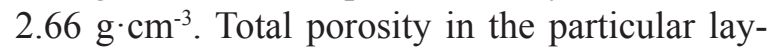
ers assumes values from 30.6 to $46.4 \%$. The soils in both pits are characterised by similar physicalhydraulic properties, and their land use type and supply with precipitation waters are identical. The factor that differentiates the soil profiles is the depth of the groundwater table.

The first stage of the study was the verification, tabulation and comparison of results of values of volumetric moisture obtained with the two methods for both profiles. The characteristic values were calculated (minimum, maximum, mean value, median) as well as the classical statistical measures [Łomnicki 2007]. The results of the calculations are presented in Table 1.

For soil profile B (valley area below the barrage) the minimum values, the mean values and the median are lower relative to the values for profile A (the differences vary from 3.04 percentage points to 5.90 for the minimum value). Whereas, the maximum values for the two soil profiles are at a similar level. For all of the characteristic values the results obtained with the gravimetric method are higher by an average of 5.17 percentage points than the results obtained by means of TDR probes. The analysis of range indicates that in profile $\mathrm{B}$ a bigger spectrum of measured moisture values is observed than in profile A. Lower values of standard deviation in profile A indicate that the observations are more concentrated around the mean value than those obtained for profile B. For moisture values measured with the two methods the values of range and of standard deviation are comparable for both soil profiles. As opposed to standard deviation which defines the absolute variation of a feature, the coefficient of variation is a relative measure, depends on the value of arithmetic mean [Łomnicki 2007]. The coefficients of variation calculated for profiles A and $\mathrm{B}$ show that in the case of profile $\mathrm{B}$ a greater variation of data is noted than in profile $\mathrm{A}$. The coefficients of variation for the two methods under comparison show a notably greater variation of the data in the case of TDR probes (difference between coefficient of variation are from $1.23 \%$ for profile A and $8.09 \%$ for profile B).

Figures 2-4 present the correlations between volumetric moisture values obtained with the gravimetric method and with the use of TDR probes, and the equations of regression (where: $x$ - moisture determined with the gravimetric method, $y$ - moisture determined with the TDR method) and the coefficient of determination $\left(R^{2}\right)$.

On the basis of the coefficients of determination obtained for both profiles the coefficients of correlation were calculated and the character of the relation was determined [Byczkowski 1979]. Table 2 presents the coefficients of determination and correlation obtained, and the interpretation of the character of the relationship. The value of the coefficient of correlation at the level of 0.8 obtained in the comparison of all the data indicates a strong relation between the results of measurements made with the use of the gravimetric method and the TDR method. Taking into account only the data for profile A, the calculated value of the coefficient of correlation is 0.7 , which means a relationship between weak and

Table 1. Characteristic values and selected classical statistical measures

\begin{tabular}{|c|c|c|c|c|c|c|}
\hline \multirow{2}{*}{ Specification } & \multicolumn{2}{|c|}{ All data } & \multicolumn{2}{|c|}{ Profile A } & \multicolumn{2}{|c|}{ Profile B } \\
\hline & GRV & TDR & GRV & TDR & GRV & TDR \\
\hline Minimum value & 6.63 & 3.20 & 9.67 & 9.10 & 6.63 & 3.20 \\
\hline Maximum value & 44.00 & 36.85 & 41.00 & 34.20 & 44.00 & 36.85 \\
\hline Mean value & 24.13 & 18.69 & 26.94 & 21.52 & 21.78 & 16.31 \\
\hline Median & 23.89 & 18.70 & 26.71 & 20.78 & 21.00 & 15.00 \\
\hline Standard deviation & 8.06 & 7.23 & 6.64 & 5.56 & 8.41 & 7.62 \\
\hline Variance & 64.89 & 52.22 & 44.03 & 30.96 & 70.69 & 58.01 \\
\hline Range & 37.37 & 33.65 & 31.33 & 25.10 & 37.37 & 33.65 \\
\hline Coefficient of variation & 33.38 & 38.67 & 24.63 & 25.86 & 38.59 & 46.69 \\
\hline
\end{tabular}




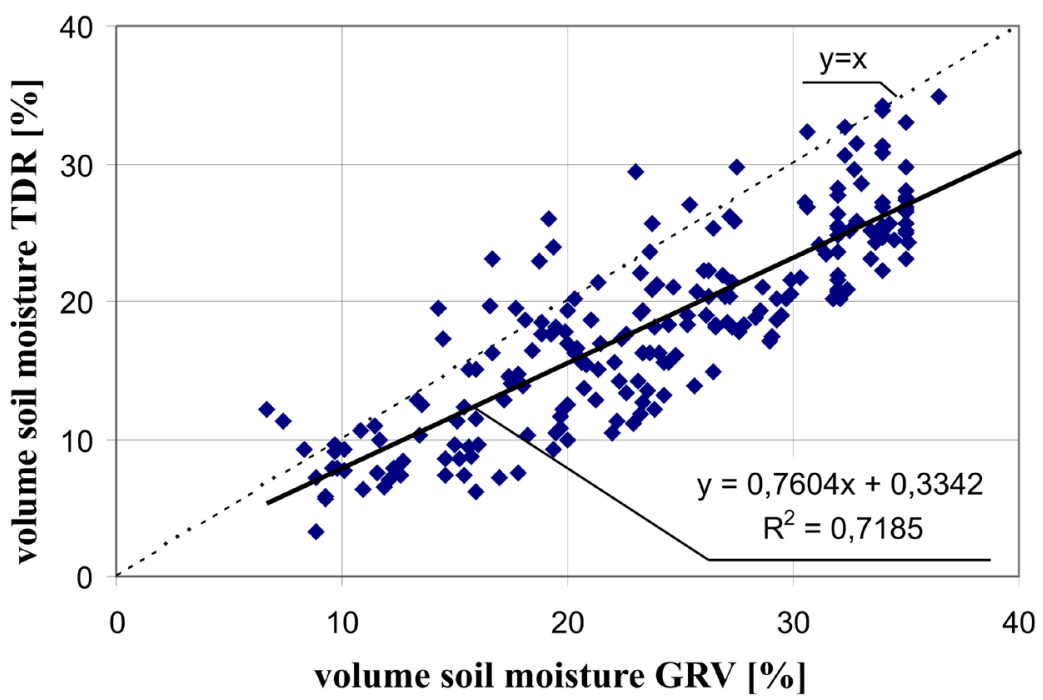

Figure 2. Comparison of results of volumetric moisture measurement with TDR method and gravimetric method (GRV) for two soil profiles

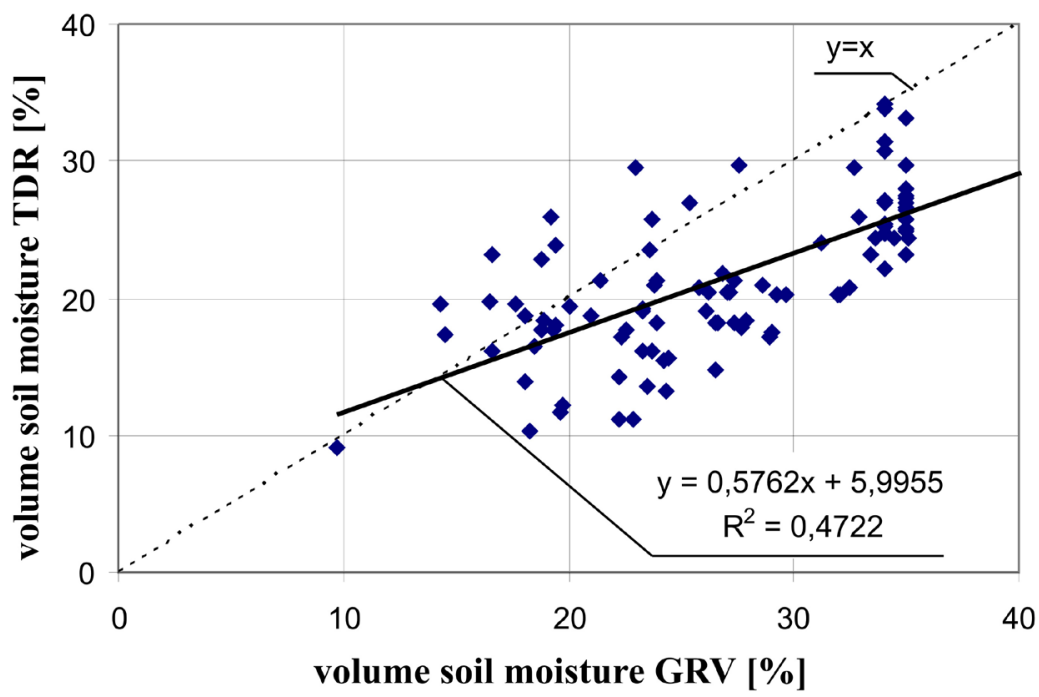

Figure 3. Comparison of results of volumetric moisture measurement with TDR method and gravimetric method (GRV) for profile A

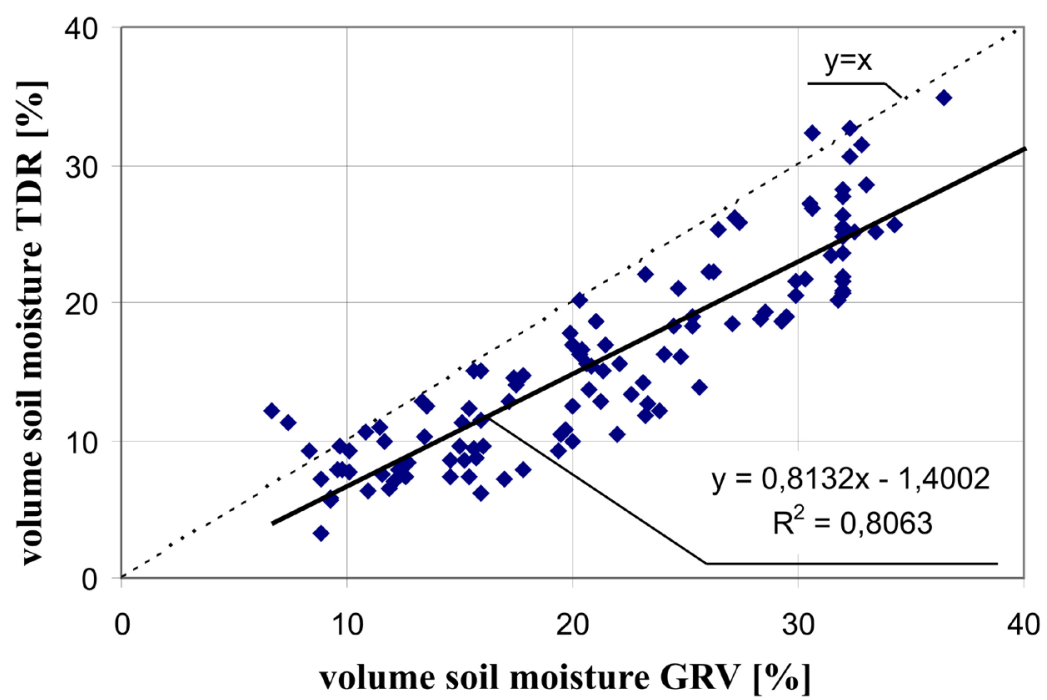

Figure 4. Comparison of results of volumetric moisture measurement with TDR method and gravimetric method (GRV) for profile B 
Table 2. Correlation levels and their interpretation

\begin{tabular}{|l|c|c|c|}
\hline \multicolumn{1}{|c|}{ Specification } & All data & Profile A & Profile B \\
\hline Coefficient of determination & 0.72 & 0.47 & 0.81 \\
\hline Coefficient of correlation & 0.8 & 0.7 & 0.9 \\
\hline Character of relationship & strong & weak/strong & strong/very strong \\
\hline
\end{tabular}

strong. The coefficient of correlation for data from profile $B$ has the value of 0.9 , indicating correlation of the relationship between strong and very strong.

\section{CONCLUSIONS}

1. Volumetric moisture values obtained with the gravimetric method are higher than those obtained by means of TDR probes.

2. A higher level of correlation was obtained for profile B, situated in the valley below the barrage in Brzeg Dolny, where lower values of volumetric moisture are observed compared to the values for profile $\mathrm{A}$.

3. The analysis and comparison of the measurement results obtained indicate that the values of volumetric moisture acquired with the two methods under analysis are comparable.

\section{REFERENCES}

1. Bac S., Koźmiński C., Rojek M., 1998. Agrometeorologia. Wydawnictwo Naukowe PWN, Warszawa.

2. Biniak-Pieróg M. 2008. Wpływ elementów agrometeorologicznych na zmienność zasobów wodnych gleby w półroczu zimowym. Monografia. Seria: Współczesne problemy inżynierii środowiska. Wyd. Uniw. Przyr., Nr 7, Wrocław.

3. Byczkowski A. 1979. Hydrologiczne podstawy projektów wodnomelioracyjnych przepływy charakterystyczne. PWRiL, Warszawa.

4. Janik G., 2005. Próba zastosowania reflektometrii domenowo czasowej (TDR) do szacowania spływu powierzchniowego. Zeszyty Naukowe Akademii Rolniczej w Krakowie, z. 26, Inżynieria Środowiska, nr 420, 83-91.

5. Leciejewski P. 2009. Wykorzystanie metody TDR do ciągłego pomiaru zmian warunków wilgotnościowych i termicznych w profilu glebowym. Studia i Materiały Centrum Edukacji Przyrodniczo-Leśnej, 11, 2(21), 235-246.
6. Kossowski J., Usowicz B. 2000. Charakterystyka pola wilgotności gleby przy różnej liczbie próbkowań. Acta Agrophysica, 38, 127-137.

7. Marcilonek S., 1979. Eksploatacja urządzeń melioracyjnych. PWRiL, Warszawa.

8. Malicki M.A. 1993. Wpływ fizycznych właściwości gleby na elektryczne parametry układu elektrody/ gleba w aspekcie pomiaru jej wilgotności i zasolenia. Acta Agrophysica, rozprawa habilitacyjna, Instytut Agrofizyki PAN w Lublinie, Lublin.

9. Łomnicki A. 2007. Wprowadzenie do statystyki dla przyrodników. Wydawnictwo Naukowe PWN, Warszawa

10. Skierucha W., Wilczek A., 2007. Polowy system monitorowania wilgotności gleby. PAK, 53, 9bis, Lublin.

11. Łyczko W., Olszewska B., Pływaczyk L. 2000. Porównanie metody TDR oraz metody suszarkowo-wagowej do określania uwilgotnienia różnych typów gleb w dolinie Odry. Zeszyty Naukowe Akademii Rolniczej we Wrocławiu, 385.

12. Pęczkowski G., Żyromski A., Kostrzewa S., Zastosowanie metody TDR (Time Domain Reflektometry) do pomiaru uwilgotnienia glin z dużą zawartością szkieletu. Inżynieria Ekologiczna, 18, 200-202.

13. Oleszczuk R., Brandyk T., Szatyłowicz J., 1998. Analiza możliwości zastosowania metody TDR do pomiaru uwilgotnienia w glebie torfowo-murszowej. Zesz. Probl. Post. N. Roln., 458, 263-274.

14. Oleszczuk R., Brandyk T., Szatyłowicz J., 2006. Porównanie różnych sposobów określania zapasów wody w glebie torfowo-murszowej użytkowanej łąkowo. Acta Agrophysica, 8(1), 11-21.

15. Olszewska B., 1998. Wpływ budowli piętrzącej na warunki wodne oraz wybrane elementy środowiska przyrodniczego w dolinie na przykładzie Odry w rejonie Brzegu Dolnego. Zeszyty Naukowe Akademii Rolniczej we Wrocławiu, 349.

16. Pływaczyk L., 1997. Oddziaływanie spiętrzenia rzeki na dolinę na przykładzie Brzegu Dolnego. Wyd. AR Wrocław, Monografie XI, Wrocław.

17. Usowicz, B., Usowicz, Ł., 2004. Punktowe pomiary wilgotności gleb, a jej przestrzenny rozkład na polach uprawnych. Acta Agrophysica, 4(2), 573-588. 